\section{Effects of Short Interval Cyclic Flooding on Growth and Survival of Three Native Shrubs}

\author{
Katie L. Dylewski ${ }^{1,3}$, Amy N. Wright ${ }^{1}$, Kenneth M. Tilt ${ }^{1}$, \\ and Charlene LeBleu ${ }^{2}$
}

ADDITIONAL INDEX WORDs. inkberry holly, sweetspire, possumhaw, rain garden, flood tolerance, landscape

SuMMARY. The effect of short interval cyclic flooding on root and shoot growth of 'Shamrock' inkberry holly (Ilex glabra), 'Henry's Garnet' sweetspire (Itea virgin$i c a$ ), and 'Winterthur' possumhaw (Viburnum nudum) was studied in a greenhouse in Auburn, AL. Liners (4.4 inches long) of each species were planted into trade 1 -gal pots in 1 pine bark: 1 peat by volume (PB:P) or fine textured calcined clay (CC). 'Shamrock' inkberry holly and 'Henry's Garnet' sweetspire were planted 18 Apr. 2008; the experiment was repeated with the addition of 'Winterthur' possumhaw on 16 June 2008. Plants were flooded to substrate level for 0 (non-flooded), 3, or 7 days. Flooding cycles were repeated at least five times with 7 days of draining between each flood cycle. During draining, plants received no irrigation. Nonflooded plants were watered as needed. Flooded plants for all species except 'Winterthur' possumhaw showed decreased root dry weight, shoot dry weight, and final growth index when compared with non-flooded plants. Survival was higher in CC than PB:P for both experiments. All plants maintained good visual quality and shoot growth. As a result, overall, these plants seemed tolerant of flooding despite differences in growth.

$\mathrm{W}$ ater conservation practices have become a focal point for many communities because of drought conditions and water restrictions. With increasing urbanization and impervious surface cover, groundwater recharge has decreased (Dietz and Clausen, 2005). Additionally, pumping of groundwater supplies has increased resulting in a need for stormwater management practices that focus on infiltration to maximize groundwater recharge (Dussaillant et al., 2005). When the amount of groundwater pumped exceeds the amount of recharge, aquifers become deficient (Seo et al., 2008). Rain gardens are a homeowner stormwater management practice that can improve groundwater recharge while providing an aesthetically pleasing addition to the landscape.

Non-point source pollution has become a critical issue for both homeowners and agricultural entities in terms of groundwater supplies and water quality (Dietz and Clausen, 2008)

Authors thank J. Raymond Kessler for statistical assistance.

${ }^{1}$ Department of Horticulture, Auburn University, Auburn, AL 36849

${ }^{2}$ Department of Landscape Architecture, Auburn University, Auburn, AL 36849

${ }^{3}$ Corresponding author. E-mail: wernekl@auburn.edu. with over half of the U.S. population depending on underground sources for potable water (Cabrera, 2005). Impervious surfaces such as concrete increase stormwater runoff. Fertilizers, chemicals, and fecal matter are carried by stormwater runoff to nearby storm drains and ultimately into surface waters, resulting in decreased water quality (Dunnett and Clayden, 2007). The U.S. Environmental Protection Agency (USEPA) reported in 2001 that at least half of the U.S. waters cannot sustain aquatic life because of the presence of excess nutrients (Cabrera, $2005)$. Rain gardens and bioretention areas are considered best management practices in the collection of stormwater, allowing it to seep into the ground while filtering out harmful pollutants (Dietz and Clausen, 2006; Maryland Department of Environmental Resources, 2007; Shuster et al., 2007; USEPA, 1983).
Residential and commercial landscapes can be designed to effectively manage stormwater and encourage infiltration. A rain garden is a shallow depression that collects and stores stormwater runoff from a roof, parking lot, or any other impervious surface for a short period of time (Dussaillant et al., 2005). Rain gardens use vegetation, soil, and mulch to cycle nutrients and evaporate stormwater. Rain gardens depend on seasonal precipitation as their water source. Therefore, during precipitation events, rain gardens may flood and remain saturated above the substrate level until water permeates the ground. Dussaillant et al. (2005) found that soil in a rain garden would likely remain saturated for $1-2 \mathrm{~d}$ and that plant roots should be able to withstand at least $2 \mathrm{~d}$ of standing water in the root zone for optimal recharge to occur. This is true for most standard rain gardens in well-drained soils; however, rain gardens sited on clay or clay-loam soils are considered wet rain gardens and may remain flooded for longer than $2 \mathrm{~d}$. Therefore, plants selected for wet rain gardens may need to be tolerant of flooding for longer periods of time due to decreased infiltration rates.

Cyclic flooding has been used to evaluate agricultural crops and wetland species. Cyclic flooding consists of a cycle of flooding and draining that is repeated over time, similar to what a rain garden might experience in the landscape. Rain gardens are selfsustaining environments that only receive irrigation during a rain event and, as a result, may remain dry for a period of weeks until the next rain event regardless of soil type. Native plants adapted to low wetland areas are desirable for rain gardens because they are low maintenance, not invasive, relatively pest free (North Carolina Cooperative Extension, 2009), and usually able to persist during periods of low rainfall or drought once established (Dunnett and Clayden, 2007).

\begin{tabular}{llll}
\hline $\begin{array}{l}\text { Units } \\
\text { To convert U.S. to SI, } \\
\text { multiply by }\end{array}$ & U.S. unit & SI unit & $\begin{array}{l}\text { To convert SI to U.S., } \\
\text { multiply by }\end{array}$ \\
\hline 29.5735 & $\mathrm{fl} \mathrm{oz}$ & $\mathrm{mL}$ & 0.0338 \\
3.7854 & gal & $\mathrm{L}$ & 0.2642 \\
2.54 & inch $(\mathrm{es})$ & $\mathrm{cm}$ & 0.3937 \\
0.5933 & $\mathrm{lb} / \mathrm{yard}^{3}$ & $\mathrm{~kg} \cdot \mathrm{m}^{-3}$ & 1.6856 \\
28.3495 & $\mathrm{OZ}$ & $\mathrm{g}$ & 0.0353 \\
$\left({ }^{\circ} \mathrm{F}-32\right) \div 1.8$ & ${ }^{\circ} \mathrm{F}$ & ${ }^{\circ} \mathrm{C}$ & $\left(1.8 \times{ }^{\circ} \mathrm{C}\right)+32$
\end{tabular}


There has been little research evaluating specific plants for use in rain gardens. A variety of plant recommendation lists are available, but they are not based on data from replicated experiments [Cabrera, 2005; Ranney et al., 1998; U.S. Department of Agriculture (USDA), 2008; U.S. Fish and Wildlife Service, 1996 (USFWS)]. Such lists include, but are not limited to: "Qualifiers for quagmires: Landscape plants for wet sites" (Ranney et al., 1998); wetlands vascular plant species list (USFWS, 1996); "Plants for rain gardens" (Glen, 2009); "Wetland indicator status list" (USDA, 2008); "Shrubs for bioretention areas" (North Carolina Division of Water Quality, 2009); and lists of plants recommended for southern rain gardens (Kraus and Spafford, 2009). These lists were referred to to select plants used in this experiment. Since rain gardens may remain flooded for $2 \mathrm{~d}$ or longer depending on soil infiltration rate, plants should be able to survive and grow under periods of anaerobic conditions. The objective of this study is to determine the effects of short interval cyclic flooding on selected native shrubs intended for use in rain gardens, using substrates to simulate conditions in a standard and wet rain garden.

\section{Materials and methods}

ExPT. I. On 18 Apr. 2008, thirty 4.4-inch-long rooted stem cuttings of 'Shamrock' inkberry holly and 'Henry's Garnet' sweetspire (Spring Meadow Nursery, Grand Haven, MI) were planted into trade gal pots with drainage holes. Liners were $\approx 6$ months old at planting. At planting, root balls were submersed in a solution of $0.5 \%$ $(\mathrm{w} / \mathrm{v})$ methylene blue for $10 \mathrm{~s}$ to facilitate identification of new root growth outside of the original root ball. Two substrates were used to determine a suitable substrate for evaluating plants for rain gardens. Substrates used were 1 pine bark: 1 sphagnum peat (by volume) referred to hereafter as $\mathrm{PB}: \mathrm{P}$ or fine textured calcined clay referred to hereafter as CC (Profile Products, Buffalo Grove, IL); both substrates were amended with $2 \mathrm{lb} /$ yard ${ }^{3}$ dolomitic limestone and 13.8 $\mathrm{lb} /$ yard $^{3} 15 \mathrm{~N}-2.64 \mathrm{P}-9.96 \mathrm{~K}$ controlledrelease fertilizer (8-month, Polyon ${ }^{\circledR}$; Pursell Industries, Sylacauga, AL). Calcined clay is a mineral substrate that is well-drained and similar to a sandy soil. Pine bark:peat is an organic substrate that is water retaining and similar to clay or clay-loam soils. Plants were arranged on benches in a polycarbonate greenhouse on campus of Auburn University in Auburn, AL. The greenhouse was ventilated and maintained at a minimum night temperature of $65^{\circ} \mathrm{F}$ and a maximum day temperature of $80{ }^{\circ} \mathrm{F}$ with natural photoperiods (maximum light intensity $\left.1100 \mu \mathrm{mol} \cdot \mathrm{m}^{-2} \cdot \mathrm{s}^{-1}\right)$.

Treatments were initiated on 12 May 2008 [24 d after planting (DAP)]. Plants were flooded for 0 (non-flooded), 3, or $7 \mathrm{~d}$. Flooded conditions were created by nesting a container with drainage holes that contained a plant inside a trade gal exterior container without drainage holes. Plants were flooded to the level of the substrate by adding $\approx 1 \mathrm{~L}$ tap water on the first day of flooding and adding $\approx 50 \mathrm{~mL}$ tap water on each additional flood day to maintain water table at substrate level. At the end of each flood cycle, the exterior container was removed and plants were allowed to drain for 1 week, and no water was added until the next flood cycle began. Percent moisture was measured daily between 9:00 and 11:00 AM for two replications per substrate in control plants, using a handheld moisture probe (Theta; Delta-T Devices, Cambridge, England). Non-flooded plants were irrigated with $500 \mathrm{~mL}$ tap water when substrate percent moisture reached 25\% (Bailey, 2009; Wilkin, 2007). Substrate percent moisture was measured between 9:00 and 11:00 AM for two replications per substrate in the 3- and 7-d flood treatments every other day during the draining period. During the experiment, if a plant no longer had any living tissue visible, shoot dry weight (SDW) and root dry weight (RDW) were determined at that point. At experiment, termination roots and shoots were harvested. Shoots were removed from the root ball and dried at $155^{\circ} \mathrm{F}$ for $48 \mathrm{~h}$ to determine SDW. New roots were removed from the original root ball, washed free of substrate, and dried similarly to determine RDW. The experiment was ended on 27 Aug. 2008 (131 DAP), and plants in 3- and 7-d flood treatments experienced a total of nine and seven flood cycles, respectively. Plant growth indices $[$ height + widest width + width perpendicular to widest width) $\div 3$ ] were recorded at planting and at experiment termination. Treatments were in a 3 flooding $\times 2$ substrate factorial with five single container replications per treatment. Each species was treated as a separate experiment, and the experimental design was a split plot design with substrate as the main plot and treatments randomized within. Data were analyzed using Proc Glimmix and means separation using the TukeyKramer test $(P<0.05)$ in SAS (version 9.1; SAS Institute, Cary, NC).

Expt. II. On 16 June 2008, thirty 4.4-inch-long rooted stem cuttings of all previously listed species plus 'Winterthur' possumhaw (Spring Meadow Nursery, Grand Haven, MI) were planted into trade gal pots. Treatments were the same as Expt. I, with the following exceptions. For this experiment, the entire root ball was removed and washed for RDW when SDW was recorded. Substrate percent moisture was measured in two replications per substrate every $6 \mathrm{~h}$ using soil moisture sensors $\left(\mathrm{ECH}_{2} \mathrm{O}\right.$ model EC-5; Decagon Devices, Pullman, WA). Treatments were initiated on 21 July 2008 (35 DAP). The experiment was ended on 10 Oct. 2008 (117 DAP). Plants in the 3- and 7-d flood treatments experienced seven and five flood cycles, respectively.

\section{Results \\ 'Shamrock' Inkberry Holly}

EXPT. I. Root dry weight and SDW were higher $(P=0.0355$ and $P=0.0482$, respectively) for plants in CC (0.9 and $6.5 \mathrm{~g}$, respectively) than in $\mathrm{PB}: \mathrm{P}$ (0.5 and $4.7 \mathrm{~g}$, respectively). Root dry weight, SDW, and growth index (GI) were higher for nonflooded plants than for flooded plants (Table 1). Although not analyzed statistically $(n=2), \mathrm{PB}: \mathrm{P}$ appeared to dry down more slowly than CC, and substrate percent moisture at the end of a draining period for plants flooded for 3 and $7 \mathrm{~d}$ was $30.3 \%$ and $34.8 \%$, respectively, in PB:P and $20.9 \%$ and $25.8 \%$, respectively, in CC. All plants in CC had 100\% survival rate. Mortality was first observed at 95 DAP, and $20 \%$ of plants flooded for $3 \mathrm{~d}$ in PB:P and $40 \%$ of plants flooded for $7 \mathrm{~d}$ in PB:P were dead.

ExPT. II. There was an interaction between substrate and flooding 
treatment for RDW and SDW (Table $2)$. Root dry weight was higher in CC than in PB:P for non-flooded plants and plants flooded for $3 \mathrm{~d}$ (Table 2), and SDW for plants was higher in CC than PB:P for non-flooded plants ( $\mathrm{Ta}$ ble 2). Root dry weight and SDW in CC decreased linearly with increased flood days (Table 2); however, SDW in PB:P responded quadratically to flood treatments (Table 2). The response of RDW and SDW to $3 \mathrm{~d}$ of flooding indicates that this plant would be an excellent candidate for conditions experienced in a rain garden. Although not statistically analyzed $(n=2)$, substrate percent moisture during flooding and draining appeared similar among substrates, but not different among flood treatments. On average, substrate percent moisture during flooding was $52.2 \%$ in $\mathrm{PB}: \mathrm{P}$ and $49.0 \%$ in CC. At the end of a draining period for flooded plants, percent moisture for PB:P was $29.6 \%$ and $20.1 \%$ in CC. Although not analyzed statistically, mortality was observed only in plants flooded for $7 \mathrm{~d}$ in both substrates, and mortality rates appeared to be higher in PB:P (40\%) than in CC (20\%).

\section{‘Henry's Garnet' Sweetspire}

Expt. I. There was a significant interaction between substrate and treatment for RDW and SDW (Table $3)$. Root dry weight and SDW were higher for plants in $\mathrm{CC}$ than in PB:P for non-flooded plants (Table 3). By contrast, RDW was higher in $\mathrm{PB}: \mathrm{P}$ than in CC for plants flooded for 3 $\mathrm{d}$ but similar between substrates in plants flooded for $7 \mathrm{~d}$ (Table 3). Shoot dry weight was lower in flooded plants than in non-flooded plants in both substrates, and RDW was lower in flooded plants than in non-flooded plants in CC (Table 3). Although not analyzed statistically, mortality rates observed for plants flooded for $7 \mathrm{~d}$

Table 1. Effect of duration of flooding cycle on root dry weight (RDW) shoot dry weight (SDW), and final growth index (GI) of 'Shamrock' inkberry holly grown in a greenhouse in Auburn, AL. In May 2008, plants in the 3-and 7-d flood treatments experienced a total of nine and seven flood cycles, respectively. In July 2008, plants in the 3- and 7-d flood treatments experienced a total of seven and five flood cycles, respectively.

\begin{tabular}{|c|c|c|c|c|}
\hline \multirow[b]{2}{*}{ Flooding duration $(\mathrm{d})^{\mathrm{z}}$} & \multicolumn{3}{|c|}{ May 2008} & \multirow{2}{*}{$\frac{\text { July } 2008}{\text { GI }(\mathrm{cm})}$} \\
\hline & $\mathrm{RDW}(\mathrm{g})^{\mathrm{y}}$ & SDW (g) & $\mathrm{GI}(\mathrm{cm})^{\mathrm{x}}$ & \\
\hline 0 & $1.7 \mathrm{a}^{\mathrm{w}}$ & $9.8 \mathrm{a}$ & $25.3 \mathrm{a}$ & $20.5 \mathrm{a}$ \\
\hline 3 & $0.3 \mathrm{~b}$ & $4.2 \mathrm{~b}$ & $14.5 \mathrm{~b}$ & $16.9 \mathrm{~b}$ \\
\hline 7 & $0.02 \mathrm{~b}$ & $2.8 \mathrm{~b}$ & $13.0 \mathrm{~b}$ & $15.5 \mathrm{~b}$ \\
\hline & $\mathrm{L}^{* * * v}$ & $\mathrm{~L}^{* * *}$ & $\mathrm{~L}^{* * *}$ & $\mathrm{~L}^{* * *}$ \\
\hline Main effect significance $P$ & $<0.0001$ & $<0.0001$ & $<0.0001$ & $<0.0001$ \\
\hline
\end{tabular}

${ }^{z}$ Treatments were based on days of flooding. Plants were flooded for 0 (control), 3 , or $7 \mathrm{~d}$.

${ }^{\mathrm{y}} \mathrm{l} \mathrm{g}=0.0353 \mathrm{oz}$.

${ }^{x}$ Final GI $=$ (height + widest width + width perpendicular to widest width $) \div 3 ; 1 \mathrm{~cm}=0.3937$ inch.

whowercase letters denote mean separation within columns using Tukey-Kramer test at $P<0.05$; if no differences then letters are omitted.

${ }^{v}$ Linear trend at $\alpha \leq 0.0001\left({ }^{* *}\right), 0.001\left({ }^{* *}\right)$, and $0.01\left({ }^{*}\right)$ among treatments.

Table 2. Effect of duration of flooding cycle on root dry weight (RDW) and shoot dry weight (SDW) of 'Shamrock' inkberry holly grown in a greenhouse in Auburn, AL. In July 2008, plants in the 3-and 7-d flood treatments experienced a total of seven and five flood cycles, respectively.

\begin{tabular}{|c|c|c|c|c|c|c|c|c|}
\hline \multirow[b]{4}{*}{ Substrate $^{\mathrm{z}}$} & \multicolumn{8}{|c|}{ July 2008} \\
\hline & \multicolumn{4}{|c|}{ RDW $(g)^{y}$} & \multicolumn{4}{|c|}{ SDW (g) } \\
\hline & \multicolumn{8}{|c|}{ Flooding duration $(\mathrm{d})^{\mathrm{x}}$} \\
\hline & 0 & 3 & 7 & & $\mathbf{0}$ & 3 & 7 & \\
\hline $\mathrm{CC}$ & $8.6 \mathrm{a}^{\mathrm{w}}$ & $5.7 \mathrm{a}$ & 3.0 & $\mathrm{~L}^{* * * \mathrm{v}}$ & $10.1 \mathrm{a}$ & 7.8 & 6.2 & $\mathrm{~L}^{* *}$ \\
\hline PB:P & $3.6 \mathrm{~b}$ & $3.6 \mathrm{~b}$ & 2.1 & & $4.7 \mathrm{~b}$ & 7.1 & 4.2 & $Q^{*}$ \\
\hline Interaction significance $P$ & & 0.0372 & & & & 155 & & \\
\hline
\end{tabular}

${ }^{2} \mathrm{CC}=$ calcined clay, $\mathrm{PB}: \mathrm{P}=1$ pine bark: 1 peat by volume.

${ }^{\mathrm{y}} \mathrm{l} \mathrm{g}=0.0353 \mathrm{oz}$.

Treatments were based on days of flooding. Plants were flooded for 0 (control), 3 , or $7 \mathrm{~d}$.

wLowercase letters denote mean separation within columns using contrast statements in Proc Glimmix (SAS

version 9.1; SAS Institute, Cary, NC) at $P<0.05$; if no differences then letters are omitted.

vinear or quadratic trend at $\alpha \leq 0.0001\left({ }^{* *}\right), 0.001\left({ }^{* *}\right)$, and $0.01(*)$ among treatments.

appeared lower in CC (20\%) than in $\mathrm{PB}: \mathrm{P}(40 \%)$, but mortality was first observed in CC (57 DAP) then in $\mathrm{PB}: \mathrm{P}(113 \mathrm{DAP})$. Non-flooded plants and plants flooded for $3 \mathrm{~d}$ in $\mathrm{PB}: \mathrm{P}$ had similar mortality rates of $40 \%$ at 113 DAP; however, mortality was first observed in plants flooded for $3 \mathrm{~d}$ at 75 $\mathrm{DAP}$ with no additional plants dying after 75 DAP.

ExpT. II. Shoot dry weight and GI were higher in non-flooded plants than in flooded plants (Table 4). Root dry weight generally decreased with increasing length of flood cycle ( $\mathrm{Ta}$ ble 4). At the end of a draining period for flooded plants, percent moisture was $20.9 \%$ in $\mathrm{PB}: \mathrm{P}$ and $21.0 \%$ in CC. Substrate percent moisture during dry down of 3 - and 7-d flooded plants was $19.6 \%$ and $22.3 \%$, respectively, in $\mathrm{PB}: \mathrm{P}$ and $21.2 \%$ and $20.9 \%$, respectively, in CC. All plants in both substrates maintained $100 \%$ survival rate throughout this experiment.

\section{'Winterthur' Possumhaw}

ExPT. II. There was an interaction between substrate and treatment for RDW and SDW $(P=0.0001$ and 0.001 , respectively). Root dry weight and SDW were higher in $\mathrm{CC}$ than in PB:P for non-flooded plants (Table 5). Shoot dry weight in PB:P increased linearly with increasing flooding overall treatments (Table 5). Root dry weight was similar for plants flooded for 3 and $7 \mathrm{~d}$ in both substrates (Table 3 ). Shoot dry weight was higher in CC than in $\mathrm{PB}: \mathrm{P}$ for plants flooded for $3 \mathrm{~d}$ but not for plants flooded for $7 \mathrm{~d}$ (Table $5)$. Final GI was higher in CC $(20.2$ $\mathrm{cm})$ than in $\mathrm{PB}: \mathrm{P}(18.2 \mathrm{~cm})(P=$ $0.0432)$. There were no differences among flooding treatments for GI (data not shown). At the end of a draining period for flooded plants, percent moisture for $\mathrm{PB}: \mathrm{P}$ was $24.0 \%$ and $19.0 \%$ for plants in CC. Substrate percent moisture at the end of the draining period for plants flooded for 3 and $7 \mathrm{~d}$ was $24.4 \%$ and $23.5 \%$, respectively, in $\mathrm{PB}: \mathrm{P}$ and $16.7 \%$ and $21.3 \%$, respectively, in CC. Although not analyzed statistically, PB:P mortality rates appeared to be higher in non-flooded plants $(30 \%)$ than in plants flooded for 3 d (10\%). Calcined clay mortality appeared to be higher in plants flooded for $7 \mathrm{~d}(20 \%)$ than in plants flooded for $3 \mathrm{~d}(10 \%)$. 
Table 3. Effect of duration of flooding cycle on root dry weight (RDW) and shoot dry weight (SDW) of 'Henry's Garnet' sweetspire grown in a greenhouse in Auburn, AL. For May 2008, plants in the 3- and 7-d flood treatments experienced a total of nine and seven flood cycles, respectively.

\begin{tabular}{|c|c|c|c|c|c|c|c|c|}
\hline \multirow[b]{4}{*}{ Substrate $^{\mathrm{z}}$} & \multicolumn{8}{|c|}{ May 2008} \\
\hline & \multicolumn{4}{|c|}{$\operatorname{RDW}(\mathrm{g})^{\mathrm{y}}$} & \multicolumn{4}{|c|}{ SDW (g) } \\
\hline & \multicolumn{8}{|c|}{ Flooding duration $(d)^{x}$} \\
\hline & 0 & 3 & 7 & & $\mathbf{0}$ & 3 & 7 & \\
\hline $\mathrm{CC}$ & $8.9 \mathrm{a}^{\mathrm{w}}$ & $0.5 \mathrm{~b}$ & 0.1 & $\mathrm{~L}^{* * * \mathrm{v}}$ & $21.6 \mathrm{a}$ & 4.1 & 1.3 & $\mathrm{~L}^{* * *}$ \\
\hline $\mathrm{PB}: \mathrm{P}$ & $3.0 \mathrm{~b}$ & $3.3 \mathrm{a}$ & 0.1 & & $6.7 \mathrm{~b}$ & 5.4 & 1.1 & $\mathrm{~L}^{*}$ \\
\hline Interaction significance $P$ & \multicolumn{3}{|c|}{$<0.0001$} & \multicolumn{5}{|c|}{$<0.0001$} \\
\hline
\end{tabular}

${ }^{\mathrm{z}} \mathrm{CC}=$ calcined clay, $\mathrm{PB}: \mathrm{P}=1$ pine bark: 1 peat by volume.

$\mathrm{l} \mathrm{g}=0.0353 \mathrm{oz}$.

${ }^{x}$ Treatments were based on days of flooding. Plants were flooded for 0 (control), 3, or $7 \mathrm{~d}$.

"Lowercase letters denote mean separation within columns using contrast statements in Proc Glimmix (SAS

version 9.1; SAS Institute, Cary, NC) at $P<0.05$; if no differences then letters are omitted.

"Linear trend at $\alpha \leq 0.0001\left({ }^{* *}\right), 0.001\left({ }^{*}\right)$, and $0.01\left({ }^{*}\right)$ among treatments

Table 4. Effect of duration of flooding cycle on root dry weight (RDW), shoot dry weight (SDW), and final growth index (GI) of 'Henry's Garnet' sweetspire grown in a greenhouse in Auburn, AL. For July 2008, plants in the 3- and 7-d flood treatments experienced a total of seven and five flood cycles, respectively.

\begin{tabular}{lccc}
\hline & \multicolumn{3}{c}{ July 2008 } \\
\cline { 2 - 4 } Flooding duration $(\mathbf{d})^{\mathrm{z}}$ & RDW $(\mathbf{g})^{\mathrm{y}}$ & SDW $(\mathrm{g})$ & $\mathrm{GI}(\mathbf{c m})^{\mathrm{x}}$ \\
\hline 0 & $8.5 \mathrm{a}^{\mathrm{w}}$ & $12.6 \mathrm{a}$ & $30.7 \mathrm{a}$ \\
3 & $6.5 \mathrm{ab}$ & $8.5 \mathrm{~b}$ & $25.3 \mathrm{~b}$ \\
7 & $5.3 \mathrm{~b}$ & $6.5 \mathrm{~b}$ & $22.9 \mathrm{~b}$ \\
& $\mathrm{~L}^{* \mathrm{v}}$ & $\mathrm{L}^{* * *}$ & $\mathrm{~L}^{* *}$ \\
Main effect significance $P$ & 0.0255 & 0.0002 & 0.0004 \\
\hline
\end{tabular}

${ }^{2}$ Treatments were based on days of flooding. Plants were flooded for 0 (control), 3 , or $7 \mathrm{~d}$.

${ }^{\mathrm{y}} \mathrm{l} \mathrm{g}=0.0353 \mathrm{oz}$.

${ }^{x}$ Final GI $=$ (height + widest width + width perpendicular to widest width $) \div 3 ; 1 \mathrm{~cm}=0.3937$ inch .

"Lowercase letters denote mean separation within columns using Tukey-Kramer test at $P<0.05$; if no differences then letters are omitted.

${ }^{v}$ Linear trend at $\alpha \leq 0.0001(* * *), 0.001(* *)$, and $0.01(*)$ among treatments.

Table 5. Effect of duration of flooding cycle on root dry weight (RDW) and shoot dry weight (SDW) of 'Winterthur' possumhaw grown in a greenhouse in Auburn, AL. Plants in the 3- and 7-d flood treatments experienced a total of seven and five flood cycles, respectively.

\begin{tabular}{|c|c|c|c|c|c|c|c|c|}
\hline \multirow[b]{4}{*}{ Substrate $^{\mathrm{z}}$} & \multicolumn{8}{|c|}{ May 2008} \\
\hline & \multicolumn{4}{|c|}{$\mathrm{RDW}(\mathrm{g})^{\mathrm{y}}$} & \multicolumn{4}{|c|}{ SDW (g) } \\
\hline & \multicolumn{8}{|c|}{ Flooding duration $(\mathrm{d})^{\mathrm{x}}$} \\
\hline & 0 & 3 & 7 & & 0 & 3 & 7 & \\
\hline $\mathrm{CC}$ & $10.8 \mathrm{a}^{\mathrm{w}}$ & 6.5 & 5.8 & $L^{* * v}$ & $8.6 \mathrm{a}$ & $7.7 \mathrm{a}$ & 6.0 & \\
\hline PB:P & $3.4 \mathrm{~b}$ & 5.0 & 5.8 & & $3.4 \mathrm{~b}$ & $5.2 \mathrm{~b}$ & 6.8 & $\mathrm{~L}^{*}$ \\
\hline Interaction significance $P$ & \multicolumn{3}{|c|}{0.0001} & \multicolumn{5}{|c|}{0.0010} \\
\hline
\end{tabular}

${ }^{2} \mathrm{CC}=$ calcined clay, $\mathrm{PB}: \mathrm{P}=1$ pine bark: 1 peat by volume

${ }^{\mathrm{y}} \mathrm{l} \mathrm{g}=0.0353 \mathrm{oz}$.

xTreatments were based on days of flooding. Plants were flooded for 0 (control), 3 , or $7 \mathrm{~d}$.

wLowercase letters denote mean separation within columns using contrast statements in Proc Glimmix (SAS

version 9.1: SAS Institute, Cary, NC) at $P<0.05$; if no differences then letters are omitted.

"Linear trend at $\alpha \leq 0.001(* *)$ and $0.01\left(^{*}\right)$ among treatments.

\section{Discussion}

Results from Expt. I and II indicated that flooded plants of 'Henry's Garnet' sweetspire and 'Shamrock' inkberry holly had lower RDW, SDW, and GI than non-flooded plants. Plants may respond physiologically to flooding stress by a reduction in shoot growth and an increase in leaf abscission. Shoot elongation rate of sultana grapevine (Vitis vinifera) was reduced by $40 \%$ when plants were flooded for 5 $\mathrm{d}$ and SDWs decreased linearly as flood periods increased (Stevens and Prior, 1994). Larson et al. (1993) reported that flooded mango trees (Mangifera indica) showed a reduction in root growth and reduced shoot:root ratios compared with control plants.

In Expt. I, non-flooded plants across all species grew more than flooded plants, but plants flooded for $3 \mathrm{~d}$ appeared visually similar to non-flooded plants. Plants flooded for $7 \mathrm{~d}$ had smaller canopies as reflected in GI measurements. Flooded plants generally lost more leaves compared with non-flooded plants (data not shown). Plants flooded for $3 \mathrm{~d}$ in Expt. I appeared able to tolerate flooding since they continued to grow after an initial period of adjustment following initiation of flooded conditions. By the end of Expt. I, 'Shamrock' inkberry holly plants had visible new shoot growth in both flood treatments. In Expt. II, plants flooded for $3 \mathrm{~d}$ appeared visually similar to plants flooded for $7 \mathrm{~d}$. Flooded plants in Expt. II appeared to have denser canopies and less defoliation in comparison with flooded plants in Expt. I. This was likely due to the reduction in number of flood cycles from nine and seven flood cycles (3- and 7-d flood treatments, respectively) in Expt. I to seven and five flood cycles in Expt. II. However, other factors such as initial size and age of liners used in Expt. I compared with Expt. II, as well as seasonal climate differences, may have also contributed to overall higher quality plants observed at termination of Expt. II. Mortality of non-flooded plants of 'Henry's Garnet' sweetspire and 'Winterthur' possumhaw was more prevalent in $\mathrm{PB}: \mathrm{P}$ than in CC.

\section{Conclusions}

All species appeared tolerant of cyclic flooding, which suggests they would be appropriate selections for rain gardens. Mortality rates were generally higher in Expt. I than in Expt. II. Elevated mortality rates in Expt. I may have been due to prematurity of liners used and less acclimation of plants before flood treatment initiation. Liners used in Expt. I were shipped at the earliest possible date following winter dormancy and were smaller and perhaps less vigorous than liners used in Expt. II, which were shipped later in the season. Plants had more time to acclimate to their environment (ambient temperature and light) and become established before treatments were initiated in Expt. II (35 DAP) 
than in Expt. I (24 DAP). Higher mortality rates were associated with flooded plants across all species for both experiments. Future researchers may consider using larger containerized plants to better evaluate flood and drought tolerances of established plants for use in rain gardens. Additionally, an evaluation of a larger number of species for rain gardens would be helpful as homeowner stormwater control practices become more widespread.

Methylene blue was not useful in identifying new roots because of considerable amounts of dead roots in flooded treatments. In the past, methylene blue has been used to help identify new root growth and was found to have no effect on root or shoot growth up to $90 \mathrm{~d}$ after application (Arnold and Young, 1990; Wright et al., 2004). However, in our study, because plants were subjected to flooding, roots were more likely to rot and turn black, which made it hard to distinguish new and old roots. Therefore, harvesting only new roots was abandoned after Expt. I.

Pot-in-pot flooding methodology was determined to be an effective method for creating flooded conditions. As suspected, CC drained more quickly than $\mathrm{PB}: \mathrm{P}$, and plants in $\mathrm{CC}$ substrate experienced lower substrate percent moisture during dry down, which suggests that CC could be used to better simulate short-term drought episodes to evaluate plants for rain gardens. As previously mentioned, rain gardens rely on precipitation as their source of irrigation, and because of seasonal rainfall differences, they may experience periodic drought conditions between precipitation events. Although $\mathrm{PB}: \mathrm{P}$ did dry down during draining, a longer draining period or use of a substrate with decreased water holding capacity may be necessary to impose more severe drought circumstances likely to be experienced in a wet rain garden. The ability of all species examined in these experiments to maintain growth necessary for survival under cyclic flooded conditions suggests their tolerance to alternating hydrologic conditions that might occur in any type of rain garden.

\section{Literature cited}

Arnold, M.A. and E. Young. 1990. Use of dyes to facilitate measurement of new root growth of apple. HortScience 25:116118.

Bailey, A.L. 2009. Post-transplant irrigation scheduling of native deciduous shrub species. Auburn Univ., Auburn, AL, M.S. Thesis.

Cabrera, R.I. 2005. Challenges and advances in water and nutrient management in nursery and greenhouse crops. Agricoltura Mediterranea 135:147-160.

Dietz, M.E. and J.C. Clausen. 2006. Saturation to improve pollution retention in a rain garden. Environ. Sci. Technol. 40:1335-1340.

Dietz, M.E. and J.C. Clausen. 2005. A field evaluation of rain garden flow and pollutant treatment. Water Air Pollution 167:123-138.

Dietz, M.E. and J.C. Clausen. 2008. Stormwater runoff and export changed with development in a traditional and low impact subdivision. J. Environ. Manage. 87:560-566.

Dunnett, N. and A. Clayden. 2007. Rain gardens: Managing water sustainability in the garden and designed landscape. Timber Press, Portland, OR.

Dussaillant, A.R., A. Cuevas, and K.W. Potter. 2005. Stormwater infiltration and focused groundwater recharge in a rain garden: Simulations for different world climates. Sustainable Water Mgt. Solutions Large Cities 293:178-184.

Glen, C.D. 2009. Plants for rain gardens. 7 Dec. 2009. <http://www.nhcgov.com/ AgnAndDpt/COOP/Documents / Plants\%20for\%20Rain\%20Gardens.pdf>.

Kraus, H. and A. Spafford. 2009. Rain gardening in the south. Eno Publishers, Hillsborough, NC.

Larson, K.D., B. Schaffer, and F.S. Davies. 1993. Physiological, morphological, and growth responses of mango trees to flooding. Acta Hort. 341:152-159.

Maryland Department of Environmental Resources. 2007. The bioretention manual. 30 June 2011. <http://www. princegeorgescountymd.gov/Government/ AgencyIndex/DER/ESG/Bioretention/ pdf/Bioretention\%20Manual_2009\% 20Version.pdf $>$.
North Carolina Cooperative Extension. 2009. Stormwater and your rain garden. 7 Dec. 2009. <http://www.Bae.ncsu.edu/ topic/raingarden/Entire_handout.doc $>$.

North Carolina Division of Water Quality. 2009. Stormwater best management practices design manual. 30 June 2011. <http://portal.ncdenr.org/web/wq/ws/ su/bmp-chl2>.

Ranney, T.G., R.E. Bir, M.A. Powell, and T. Bilderback. 1998. Qualifiers for quagmires: Landscape plants for wet sites. 10 Dec. 2008. <http://www.ces.ncsu.edu/ depts/hort/hil/hil-646.html>.

Seo, S., E. Seggara, P.D. Mitchell, and D.J. Leatham. 2008. Irrigation technology adoption and its implication for water conservation in the Texas High Plains: A real options approach. Agr. Econ. 38: 47-55.

Shuster, W.D., R. Gehring, and J. Gerken. 2007. Prospects for enhanced groundwater recharge via infiltration of urban storm water runoff: A case study. J. Soil Water Conserv. 62:129-137.

Stevens, R.M. and L.D. Prior. 1994. The effect of transient waterlogging on the growth, leaf gas exchange, and mineral composition of potted sultana grapevines. Amer. J. Enol. Viticult. 45:285-290.

U.S. Department of Agriculture. 2008. Wetland indicator status list. Plants database. 10 Dec. 2008. <http://plants.usda.gov/>.

U.S. Environmental Protection Agency. 1983. Results of the nationwide urban runoff program. U.S. Environ. Protection Agency, Washington, DC.

U.S. Fish and Wildlife Serv. 1996. National list of vascular plant species that occur in wetlands: 1996 National summary. 10 Dec. 2008. <http://wetlands.fws.gov/bha/ download/1996/national.pdf>.

Wilkin, M.F. 2007. The effect of irrigation frequency on growth and physiology of native landscape shrub species. Auburn Univ., Auburn, AL, M.S. Thesis.

Wright, A.N., S.L. Warren, F.A. Blazich, and U. Blum. 2004. Root and shoot growth periodicity of Kalmia latifolia 'Sarah' and Ilex crenata 'Compacta'. HortScience 39:243-247. 